PEREIRA, AS; SILVA, GO; CARVALHO, ADF; PONIJALEKI, RS. 2017. Performance of advanced potato clones: plant vigor, tuber yield and specific gravity. Horticultura Brasileira 35: 440-444. DOI - http://dx.doi.org/10.1590/S0102-053620170321

\title{
Performance of advanced potato clones: plant vigor, tuber yield and specific gravity
}

\author{
Arione S Pereira ${ }^{1}$; Giovani O Silva ${ }^{2}$; Agnaldo DF Carvalho ${ }^{3}$; Rubens S Ponijaleki ${ }^{4}$ \\ ${ }^{1}$ Embrapa Clima Temperado, Pelotas-RS, Brasil; arione.pereira@embrapa.br; ${ }^{2}$ Embrapa Hortaliças/SPM, Canoinhas-SC, Brasil; giovani. \\ olegario@embrapa.br; ${ }^{3}$ Embrapa Hortaliças, Brasília-DF, Brasil; agnaldo.carvalho@embrapa.br; ${ }^{4}$ Embrapa SPM, Canoinhas-SC, Brasil; \\ rubens.ponijaleki@embrapa.br
}

\begin{abstract}
The aim of this work was to evaluate the performance of advanced potato clones for plant vigor, tuber yield components and specific gravity. Two sets of advanced clones and two control cultivars broadly grown in Brazil were compared. The first set, formed by 11 clones, was evaluated in the spring season of 2010 , and the second, constituted by six clones, in the autumn season of 2011, in Canoinhas, Santa Catarina State, Brazil. The design of both experiments was a randomized complete block with four replications of two rows of 10 plants each. Plant vigor, tuber yield components and specific gravity were evaluated. The data of each experiment were submitted to analysis of variance and grouping means. Plant vigor was highly influenced by the environment. In the first set, 2197-15 and CL02-05 were the best clones for tuber yield traits. '2197-15' presented potential for processing and fresh market, with high plant vigor, whereas 'CL02-05' showed potential only for fresh market, and less vigorous plants. In the second set, again the outstanding clone was CL02-05.
\end{abstract}

Keywords: Solanum tuberosum, processing, productivity, mass of tubers, agronomic traits, dry matter, breeding.

\section{RESUMO}

Desempenho de clones avançados de batata: vigor de planta, produtividade e peso específico

O objetivo do trabalho foi verificar o desempenho de clones avançados de batata em relação a vigor de planta, caracteres componentes de rendimento de tubérculos e peso específico. Foram comparados dois conjuntos de clones avançados e duas cultivares plantadas amplamente no Brasil. O primeiro conjunto, formado de 11 clones, foi avaliado na safra de primavera de 2010, e o segundo constituído de seis clones, na safra de outono de 2011, em Canoinhas-SC. O delineamento de ambos os experimentos foi blocos casualizados com quatro repetições de parcelas de duas linhas de 10 plantas cada. Foram avaliados o vigor vegetativo de planta, os componentes do rendimento de tubérculos e o peso específico. Os dados de cada experimento foram submetidos à análise de variância e de agrupamento de médias. O caráter vigor das plantas foi muito influenciado pelo ambiente. No primeiro conjunto de clones, 219715 e CL02-05 foram os melhores para os caracteres de rendimento de tubérculos, sendo que '2197-15' apresentou potencial para processamento industrial além do mercado fresco, e plantas com maior vigor, enquanto 'CL02-05' limitou o potencial apenas ao mercado fresco com plantas de menor vigor. No segundo conjunto, novamente o destaque coube ao clone CL02-05.

Palavras-chave: Solanum tuberosum, processamento industrial, produtividade, massa de tubérculos, caracteres agronômicos, matéria seca, melhoramento genético.

\section{Received on January 15, 2016; accepted on December 20, 2016}

$\mathrm{M}$ ost of the potato cultivars currently used in Brazil was developed in Europe. Under Brazilian soil and climate conditions, yields are lower in comparison with the countries of origin, because these cultivars were selected under long photoperiod and low pressure conditions of some biotic factors affecting the crop in Brazil. When cultivated under subtropical and tropical conditions of the country, these cultivars show a shorter vegetative period, and, therefore, have a lower photoassimilate production (Silva et al., 2014b). To achieve higher yields, it is necessary to use a large quantity of inputs, which may lead to lower crop sustainability (Silva et al., 2014b). Thus, the development of national cultivars adapted to the growing conditions of the several Brazilian producing regions, with resistance to the main diseases, is the most viable alternative to become the potato crop more productive and profitable to the farmers (Gadum et al., 2003).
In addition to tuber yield traits, plant vigor is very important. Silva et al. (2007) evaluated potato plants of segregating families in the first field generation, and verified correlations of medium magnitude between plant vigor and plant size, tuber number and tuber yield, indicating that the more vigorous plants produce larger, higher number and higher yield of tubers. However, in practice it is noted that careful selection is required for this trait, since clones with very vigorous plants usually also 
have a longer cycle (Bradshaw et al., 2004).

The specific gravity is another important trait, since it is related to the dry matter content in the tubers (Schippers, 1976), which interferes in the processing quality of potatoes. Higher specific gravity provides higher yield of the processing product, lesser fat absorption during frying, besides positively influencing on texture and taste of the final product (Smith, 1975).

In this way, the objective of this work was to verify the performance of advanced potato clones in relation to plant vigor, tuber yield components and specific gravity.

\section{MATERIAL AND METHODS}

Two sets of advanced potato clones of the Breeding Program of the Brazilian Agricultural Research Corporation (Embrapa) were compared to two cultivars widely cultivated in Brazil.

The experiments were carried out in Canoinhas, Santa Catarina State, Brazil (2610'38'S, 50²3'24'W, 765 m altitude), in a dystrophic Red Latosol (Embrapa, 2006) and Mesothermal Wet climate, Köppen.

The first set consisted of the following clones: F88-01-05, CL8305, CL135-06, F98-03-05, 2213-445, CL123-05, CL27-05, CL69-05, 219715, CL146-06, and CL02-05. The control cultivars were Agata and Asterix, which are widely grown in the country. The first is used for fresh market and the second, mainly for processing. This experiment was conducted in the spring crop season of 2010. The planting was carried out on August 23, 2009 and the harvest on January 5, 2010.

The second set was formed by the following clones: CL63-01, CL107-05, CL02-05, CL135-06, 2213-445, and F88-01-05. The control cultivars were also Agata and Asterix. This experiment was conducted in the fall crop season of 2011. The planting was carried out on February 23 and the harvest on June 17, 2011.

The soil of each experiment was fertilized at the planting time with $\mathrm{N}$,
$\mathrm{P}_{2} \mathrm{O}_{5}$ and $\mathrm{K}_{2} \mathrm{O}$, at doses of 120,420 and $240 \mathrm{~kg} / \mathrm{ha}$, respectively. No $\mathrm{N}$ was used as top dressing and the crop was hilled 40 days after planting. Cultural and phytosanitary treatments followed the recommendations for the region (Pereira, 2010).

A randomized complete block design with four replications was used. Plots consisted of two rows of 10 plants each. Plants were spaced $0.75 \mathrm{~m}$ between rows and $0.40 \mathrm{~m}$ within rows. Seeds type II of the basic class G3 were used. Plant vigor was assessed 50 days after plant emergency, assigning scores from 1 to 5 , being $1=$ high vigor, $2=$ moderate-high, $3=$ moderate, $4=$ moderate-low, $5=$ low vigor. After plant senescence, at 110 days after planting, tubers were harvested and evaluated for the following yield traits: total tuber mass $(\mathrm{kg} / \mathrm{plot})$, commercial tuber mass $(\mathrm{kg} / \mathrm{plot})$, which were those with diameter above $45 \mathrm{~mm}$ and free of defects like cracks and second growth; average tuber mass (g); average mass of commercial tubers (g); total number of tubers; and number of commercial tubers. The specific gravity was evaluated using a hydrometer from the Snack Food Association (Kumar et al., 2007).

After checking the normal distribution of errors by the Lilliefors test, the data of each experiment were submitted to analysis of variance, and Scott-Knott's grouping of means $(p<0.05)$, and phenotypic correlation with the use of Genes computational program (Cruz, 2013).

\section{RESULTS AND DISCUSSION}

In the first set of genotypes, the coefficients of variation (CV) were higher for the mass of commercial tuber $(23.19 \%)$, and in the second set, for plant vigor $(26.73 \%)$. These values are similar to those encountered by Silva $e t$ al. (2006), which reported CVs ranging from $17.31 \%$ to $21.03 \%$ for the tuber yield, tuber number and average tuber mass (Table 1).

The relationship between the genotypic and $\mathrm{CV}(\mathrm{CVg} / \mathrm{CV})$ was lower for average commercial tuber mass (0.62), total tuber number (0.74), and plant vigor (0.77) in the second set of genotypes. This indicates that the environmental variation surpassed the genetic variation for these traits. However, for the other traits in both sets of genotypes, the $\mathrm{CVg} / \mathrm{CV}$ ratio was close to or higher than the unit, indicating a favorable condition for selection. Traits such as tuber mass and tuber number are quantitative, and therefore suffer greater environmental influence than qualitative traits, which is due to the fact that every phenotypic trait is determined by a genetic component and environment. As quantitative traits are determined by the sum of the action of several genes, the environmental influence tends to be greater than for traits controlled by few genes (Falconer \& Mackay, 1996). Silva et al. (2006) also verified high coefficient of environmental variation for these traits.

On the first set of genotypes, grouping means of clones and cultivars, provided the formation of two groups of plant vigor. A group with high vigor included 'Asterix', which was included in this study as a control cultivar for processing, with grades varying from 2.0 to 3.0, and a low vigor group which included the control 'Agata', the control for fresh market, with grades varying from 3.3 to 4.3 .

In practice, high vigorous cultivars (plants of large size) usually have long vegetative cycles (Bradshaw et al., 2004). In this study (Table 2), plant vigor was correlated with yield components with correlations of -0.677 and -0.950 (the results are negative because the scores for greater vigor correspond to low values) for total tuber mass, -0.772 and -0.904 for commercial tuber mass, -0.677 and -0.878 for average tuber mass, respectively, for the years 2010 and 2011, and -0.833 for both years, in addition to -0.637 for average commercial tuber mass in 2011. Correlations between vigor and plant size (0.40), tuber number (0.31), and tuber yield (0.42) were moderate as was observed by Silva et al. (2007), in segregating potato families in the first clonal generation. It indicates that vigorous plants produce larger plants, with higher tuber number and higher tuber yield. This is probably due to 
Table 1. Phenotypic coefficients of variation $(\mathrm{CV})$, relation between genotypic and phenotypic coefficient of variation $(\mathrm{CVg} / \mathrm{CV})$, and general mean, for phenotypic traits of 11 advanced potato clones in the spring season of 2010, and six clones in the autumn season of 2011, and two cultivars. Canoinhas, Embrapa Hortaliças/SPM, 2017.

\begin{tabular}{|c|c|c|c|c|c|c|c|c|}
\hline \multirow{2}{*}{ Clone } & \multicolumn{8}{|c|}{ Spring crop season } \\
\hline & Vigor & MTT & MTC & MMT & MMC & NTT & NTC & $\mathbf{P E}$ \\
\hline Agata & $4.3 \mathrm{a}$ & $23.08 b$ & $13.88 \mathrm{~b}$ & $91.4 \mathrm{c}$ & $154.9 \mathrm{c}$ & $152.0 \mathrm{~b}$ & $53.8 \mathrm{~b}$ & $1.062 \mathrm{~g}$ \\
\hline $2213-445$ & $4.0 \mathrm{a}$ & $31.72 b$ & $18.72 b$ & $95.5 \mathrm{c}$ & $167.4 \mathrm{c}$ & $197.3 \mathrm{a}$ & $63.0 \mathrm{~b}$ & $1.071 \mathrm{~d}$ \\
\hline CL146-06 & $4.0 \mathrm{a}$ & $30.25 b$ & $16.33 b$ & $89.4 \mathrm{c}$ & $146.8 \mathrm{c}$ & $205.3 \mathrm{a}$ & $66.3 b$ & $1.073 \mathrm{~d}$ \\
\hline CL83-05 & $3.8 \mathrm{a}$ & $25.63 b$ & $15.08 \mathrm{~b}$ & $90.3 \mathrm{c}$ & $148.7 \mathrm{c}$ & $172.0 \mathrm{~b}$ & $60.8 \mathrm{~b}$ & $1.069 \mathrm{e}$ \\
\hline F88-01-05 & $3.5 \mathrm{a}$ & $38.67 \mathrm{a}$ & $26.58 \mathrm{a}$ & $107.0 \mathrm{c}$ & $169.3 \mathrm{c}$ & $216.8 \mathrm{a}$ & $96.8 \mathrm{a}$ & $1.075 \mathrm{c}$ \\
\hline CL02-05 & $3.3 \mathrm{a}$ & $39.33 \mathrm{a}$ & $33.05 \mathrm{a}$ & $146.5 \mathrm{a}$ & $217.3 \mathrm{a}$ & $162.8 \mathrm{~b}$ & $91.5 \mathrm{a}$ & $1.065 \mathrm{f}$ \\
\hline CL69-05 & $3.3 \mathrm{a}$ & $34.38 \mathrm{a}$ & $24.55 \mathrm{a}$ & $116.6 \mathrm{~b}$ & $186.9 \mathrm{~b}$ & $178.0 \mathrm{~b}$ & $80.3 \mathrm{a}$ & $1.074 \mathrm{c}$ \\
\hline CL123-05 & $3.3 \mathrm{a}$ & $27.13 b$ & $18.58 b$ & $108.0 \mathrm{c}$ & $166.6 \mathrm{c}$ & $153.3 b$ & $67.0 \mathrm{~b}$ & $1.071 \mathrm{~d}$ \\
\hline CL27-05 & $3.3 \mathrm{a}$ & $25.22 b$ & $17.80 \mathrm{~b}$ & $97.4 \mathrm{c}$ & $135.6 \mathrm{c}$ & $157.0 \mathrm{~b}$ & $80.5 \mathrm{a}$ & $1.073 \mathrm{~d}$ \\
\hline $2197-15$ & $3.0 \mathrm{~b}$ & $35.58 \mathrm{a}$ & $27.17 \mathrm{a}$ & $145.2 \mathrm{a}$ & $210.3 \mathrm{a}$ & $148.3 b$ & $78.3 \mathrm{a}$ & $1.081 \mathrm{a}$ \\
\hline CL135-06 & $2.8 \mathrm{~b}$ & $33.17 \mathrm{a}$ & $25.08 \mathrm{a}$ & $125.3 b$ & $182.3 b$ & $157.8 \mathrm{~b}$ & $84.0 \mathrm{a}$ & $1.065 \mathrm{f}$ \\
\hline Asterix & $2.8 \mathrm{~b}$ & $37.13 \mathrm{a}$ & $28.80 \mathrm{a}$ & $129.8 b$ & $177.2 \mathrm{~b}$ & $173.5 b$ & $98.5 \mathrm{a}$ & $1.077 \mathrm{~b}$ \\
\hline F98-03-05 & $2.0 \mathrm{~b}$ & $43.72 \mathrm{a}$ & $32.50 \mathrm{a}$ & $122.5 \mathrm{~b}$ & $180.6 \mathrm{~b}$ & $216.3 \mathrm{a}$ & $108.0 \mathrm{a}$ & $1.071 \mathrm{~d}$ \\
\hline CV $(\%)$ & 19.04 & 17.48 & 23.19 & 14.10 & 14.27 & 14.61 & 19.75 & 0.25 \\
\hline $\mathrm{CVg} / \mathrm{CV}$ & 0.88 & 0.97 & 1.12 & 1.16 & 0.82 & 0.82 & 0.92 & 1.10 \\
\hline \multirow[t]{2}{*}{ Average } & 3.3 & 32.69 & 22.93 & 112.7 & 172.6 & 176.2 & 79.1 & 1.071 \\
\hline & \multicolumn{8}{|c|}{ Fall crop season } \\
\hline Agata & $4.0 \mathrm{a}$ & $13.88 \mathrm{~d}$ & $6.42 \mathrm{~d}$ & $77.5 b$ & $157.1 \mathrm{~b}$ & $108.0 \mathrm{~b}$ & $25.0 \mathrm{c}$ & $1.076 \mathrm{~d}$ \\
\hline Asterix & $3.0 \mathrm{a}$ & $20.47 b$ & $12.75 b$ & $114.2 \mathrm{a}$ & $195.5 \mathrm{a}$ & $109.5 b$ & $42.0 \mathrm{~b}$ & $1.091 \mathrm{a}$ \\
\hline CL107-05 & $3.0 \mathrm{a}$ & $20.22 b$ & $12.42 \mathrm{~b}$ & $93.8 \mathrm{~b}$ & $157.1 \mathrm{~b}$ & $132.8 \mathrm{a}$ & $51.3 \mathrm{a}$ & $1.084 \mathrm{~b}$ \\
\hline $2213-445$ & $3.0 \mathrm{a}$ & $17.83 \mathrm{c}$ & $9.80 \mathrm{c}$ & $97.4 \mathrm{~b}$ & $165.0 \mathrm{~b}$ & $114.0 \mathrm{~b}$ & $39.0 \mathrm{~b}$ & $1.080 \mathrm{c}$ \\
\hline CL88-05 & $2.8 \mathrm{a}$ & $22.33 b$ & $13.92 b$ & $105.1 \mathrm{~b}$ & $174.4 \mathrm{~b}$ & $128.3 \mathrm{a}$ & $50.3 \mathrm{a}$ & $1.085 \mathrm{~b}$ \\
\hline CL63-01 & $2.8 \mathrm{a}$ & $20.22 b$ & $13.63 b$ & $111.6 \mathrm{a}$ & $187.7 \mathrm{a}$ & $108.8 \mathrm{~b}$ & $44.0 \mathrm{~b}$ & $1.082 \mathrm{~b}$ \\
\hline R91.121-17 & $2.5 \mathrm{a}$ & $21.63 b$ & $11.00 \mathrm{c}$ & $97.9 \mathrm{~b}$ & $158.7 \mathrm{~b}$ & $133.8 \mathrm{a}$ & $42.8 \mathrm{~b}$ & $1.084 \mathrm{~b}$ \\
\hline CL02-05 & $1.5 \mathrm{~b}$ & $26.00 \mathrm{a}$ & $18.67 \mathrm{a}$ & $134.6 \mathrm{a}$ & $205.7 \mathrm{a}$ & $121.0 \mathrm{a}$ & $55.8 \mathrm{a}$ & $1.072 \mathrm{e}$ \\
\hline CV (\%) & 26.73 & 13.57 & 20.30 & 16.73 & 13.60 & 10.18 & 16.54 & 0.24 \\
\hline $\mathrm{CVg} / \mathrm{CV}$ & 0.77 & 1.16 & 1.32 & 0.82 & 0.62 & 0.74 & 1.20 & 1.22 \\
\hline Average & 2.8 & 20.32 & 12.33 & 104.0 & 175.2 & 119.5 & 43.8 & 1.082 \\
\hline
\end{tabular}

Vigor: $1=$ high vigor, $2=$ medium-high vigor, $3=$ medium vigor, $4=$ medium-low vigor, $5=$ low vigor; $\mathrm{MTT}=$ total tuber $y i e l d(\mathrm{t} / \mathrm{ha})$; $\mathrm{MTC}=$ marketable tuber yield $(\mathrm{t} / \mathrm{ha})$; MMT= average tuber weight $(\mathrm{g})$; MMC= average weight of marketable tubers $(\mathrm{g})$; NTT= total number of tubers per plot; $\mathrm{NTC}=$ number of marketable tubers per plot; $\mathrm{PE}=$ specific gravity. Means followed by the same letter, in each column, belong to the same group (Scott-Knott, 5\%).

the longer time necessary to perform photosynthesis and provide higher yield (Silva et al., 2012), which occurs until the end of the plant cycle (Pohl et al., 2009). In another study Salamoni et al. (2000) did not verify correlation between plant vigor and sugar content and dry matter content in potato tubers, agreeing with the present work regarding the specific gravity.

Also for the first set of genotypes, we verified that the control cultivar Asterix was more productive than Agata, for both total number and total mass of tubers. 'Asterix' had a total number of tubers per plot of 173.5 , total yield of $37.13 \mathrm{t} / \mathrm{ha}$, and 'Agata' had a total number of 152.0 tubers per plot and total yield of $23.08 \mathrm{t} / \mathrm{ha}$. 'Asterix' produced 98.5 tubers per plot and $28.8 \mathrm{t} / \mathrm{ha}$ of marketable tubers. 'Agata' produced 53.8 tubers per plot and $13.88 \mathrm{t} / \mathrm{ha}$ of marketable tubers. Among the advanced clones, except for the total number of tubers, '219715 ' and 'CL02-05' were the best for the evaluated trait set; combining tuber number with commercial tuber size, total and commercial tuber mass, and average tuber mass. In addition, '219715 ' presented the highest specific gravity (1.081), a trait related to dry matter content and important for the processing 
Table 2. Phenotypic coefficients of correlation, for traits evaluated in two commercial potato cultivars and 11 advanced clones in the spring season of 2010 (down diagonal), and two commercial cultivars and six clones in the autumn season of 2011 (upper diagonal). Canoinhas, Embrapa Hortaliças/SPM, 2017.

\begin{tabular}{lcccccccc}
\hline & Vigor & MTT & MTC & MMT & MMC & NTT & NTC & PE \\
\hline Vigor & 1.000 & $-0.950^{*}$ & $-0.904^{*}$ & $-0.878^{*}$ & $-0.637^{*}$ & -0.386 & $-0.833^{*}$ & 0.201 \\
MTT & $-0.677^{*}$ & 1.000 & $0.943^{*}$ & $0.865^{*}$ & $0.635^{*}$ & 0.489 & $0.917^{*}$ & 0.021 \\
MTC & $-0.772^{*}$ & $0.938^{*}$ & 1.000 & $0.936^{*}$ & $0.786^{*}$ & 0.257 & $0.904^{*}$ & -0.074 \\
MMT & $-0.677^{*}$ & $0.703^{*}$ & $0.873^{*}$ & 1.000 & $0.922^{*}$ & -0.007 & $0.735^{*}$ & -0.068 \\
MMC & -0.448 & $0.695^{*}$ & $0.802^{*}$ & $0.922^{*}$ & 1.000 & -0.350 & 0.477 & -0.059 \\
NTT & -0.055 & 0.505 & 0.202 & -0.251 & -0.158 & 1.000 & 0.578 & 0.147 \\
NTC & $-0.833^{*}$ & $0.868^{*}$ & $0.895^{*}$ & $0.639^{*}$ & 0.462 & 0.372 & 1.000 & 0.088 \\
PE & -0.322 & 0.347 & 0.275 & 0.278 & 0.168 & 0.195 & 0.338 & 1.000 \\
\hline
\end{tabular}

Vigor: $1=$ high vigor, $2=$ medium-high vigor, $3=$ medium vigor, $4=$ medium-low vigor, $5=$ low vigor; $\mathrm{MTT}=$ total tuber $y i e l d ~(\mathrm{t} / \mathrm{ha})$; $\mathrm{MTC}=$ marketable tuber yield $(\mathrm{t} / \mathrm{ha})$; MMT= average tuber weight $(\mathrm{g})$; MMC $=$ average weight of marketable tubers $(\mathrm{g})$; NTT= total number of tubers per plot; $\mathrm{NTC}=$ number of marketable tubers per plot; $\mathrm{PE}=$ specific gravity. ${ }^{*}$ Significant by the $\mathrm{T}$ test, $5 \%$.

industry, while 'CL02-05' had low specific gravity (1.065), which limits it to be indicated only to the fresh market.

The clones F88-01-05, CL135-06, F98-03-05, and CL69-05 were also grouped together with the clones of higher mass and number of commercial tubers, however, of lower average mass. The specific gravity values of the control cultivars were similar to those obtained by Pereira et al. (2008), with 1.062 and 1.070, and by Silva et al. (2012), with 1.062 and 1.082, for Agata and Asterix, respectively.

The good performance of the clones 2197-15 and CL02-05 was also verified by Silva et al. (2012), in a preliminary study carried out in Rio Grande do Sul State.

For the second set of genotypes, the Agata and Asterix cultivars were in the same plant vigor group, with scores varying from 3.0 to 4.0 . This is probably due to the greater environmental influence in this research, as discussed above. This can also be verified by the performance of the clone CL0205 , which in the second experiment formed an isolated group from the other genotypes and showed the highest plant vigor, with a score of 1.5 , while in the first set of genotypes it was less vigorous than cultivar Asterix and other clones, with score 3.3.

For the second set of clones, except for total number of tubers, the control 'Asterix' was more productive than
'Agata', in relation to both the total mass of tubers (20.47 and $13.88 \mathrm{t} / \mathrm{ha}$ ) and for the number and mass of commercial tubers, with values of 42.0 tubers per plot and yield of $12.75 \mathrm{t} / \mathrm{ha}$ for 'Asterix', and 25.0 tubers per plot and yield of 6.42 $\mathrm{t} / \mathrm{ha}$ for 'Agata'. An identical situation as observed for the first set of clones.

The clone CL02-05, which was included in the two sets of genotypes, again was the most productive. However, similarly to the first set, it presented low specific gravity (1.072), limiting its potential only to the fresh market. The clones CL107-05 and CL88-05 were among those with the highest number of tubers (132.8 and 128.3 tubers), but with smaller tubers (93.8 and 105.1 g), respectively. We concluded that, in the first set of clones, 2197-15 and CL02-05 were the best for tuber yield traits. '2197-15' presented potential for processing, because it had high specific gravity, as well as for fresh market that the appearance of tubers is also an important factor, and have plants with high vigor; whereas CL02-05 showed potential only to fresh market, with less vigorous plants. In the second set, the clone CL02-05 was again outstanding due to the high tuber yield.

In relation to other significant correlation coefficients described in Table 2, the components of yield (total tuber mass, commercial tuber mass, average tuber mass, average commercial tuber mass, and number of commercial tubers) were correlated with each other, as expected. There was no significant association between these traits and specific gravity. Silva et al. (2014b), in the evaluation of seven advanced clones and the same control cultivars of this work, also verified significant correlations between average tuber mass and total mass of tubers (0.65); number of commercial tubers (0.97), and mass of commercial tubers (0.99); and also between mass of commercial tubers and total tuber mass (0.74), and number of commercial tubers (0.92). Simon et al. (2009) found a correlation between higher total mass of tubers and higher specific gravity of moderate magnitude and significant (0.34), in the evaluation of 12 potato clones, indicating that this association is dependent on the set of clones evaluated.

\section{REFERENCES}

BRADSHAW, JE; PANDE, B; BRYAN, GJ; HACKETT, CA; MCLEAN, K; STEWART, HE. 2004. Interval mapping of quantitative trait loci for resistance to late blight [Phytophthora infestans (Mont.) de Bary], height and maturity in a tetraploid population of potato (Solanum tuberosum subsp. tuberosum). Genetics 168: 983-995.

CRUZ, CD. 2013. Genes; a software package for analysis in experimental statistics and quantitative genetics. Acta Scientiarum 35: 271-276.

EMBRAPA, Centro Nacional de Pesquisa de Solos. 2006. Sistema Brasileiro de Classificação de Solos 2 ed. Brasília: Embrapa, 306p. 
FALCONER, DS; MACKAY, TFC. 1996. Introduction to quantitative genetics. 4.ed Edinburgh: Longman Group Limited, 464p.

GADUM, J; PINTO, CABP; RIOS, MCD. 2003. Desempenho agronômico e reação de clones de batata (Solanum tuberosum L.) ao PVY. Ciência e Agrotecnologia 27: 1484-1492.

KUMAR, P; PANDEY, S; SINGH, B; SINGH, S; KUMAR, D. 2007. Influence of source and time of potassium application on potato growth, yield, economics and crisp quality. Potato Research 50: 1-13.

PEREIRA, AS. (org). 2010. Produção de batata no Rio Grande do Sul. Sistema de Produção, 19. Pelotas: Embrapa Clima Temperado. 95p.

PEREIRA, AS; NEY, VG; TERRES, LR; TREPTOW, RO; CASTRO, LAS. 2008. Caracteres de produção e qualidade de clones de batata selecionados de população segregante para resistência ao vírus $Y d a$ batata. Pelotas: Embrapa Clima Temperado. 18p. (Boletim de Pesquisa e Desenvolvimento, 67).

POHL, S; LOPES, NF; BRAGA, EJB; SILVA,
CP; SILVA, FSP; PETERS, JA. 2009. Características de crescimento de plantas de batata, cv. Baronesa, e seu genótipo transformado geneticamente para resistência ao PVY. Revista Ceres 56: 736-743.

SALAMONI, AT; PEREIRA, AS; VIÉGAS, J; CAMPOS, AD; CHALÁ, CSA. 2000. Variância genética de açúcares redutores e matéria seca e suas correlações com características agronômicas em batata. Pesquisa Agropecuária Brasileira 35: 1441 1445.

SCHIPPERS, PA. 1976. The relationship between specific gravity and percentage of dry matter in potato tubers. American Potato Journal 53: 111-122.

SILVA, GO; CASTRO, CM; TERRES, LR; ROHR, A; SUINAGA, FA; PEREIRA, AS. 2012. Desempenho agronômico de clones elite de batata. Horticultura Brasileira 30: 557-560.

SILVA, GO; PEREIRA, AS; CARVALHO, ADF. 2014a. Seleção de clones de batata para fritura com base em índices de seleção. Ceres 61: 941-947.

SILVA, GO; PEREIRA, AS; SOUZA, VQ; CARVALHO, FIF; NETO, RF. 2006. Early generation selection for tuber appearance affects potato yield components. Crop Breeding and Applied Biotechnology 6: 73-78.

SILVA, GO; PEREIRA, AS; SOUZA, VQ; CARVALHO, FIF; NETO, RF. 2007. Correlações entre caracteres de aparência e rendimento e análise de trilha para aparência de batata. Bragantia 66: 381-388.

SILVA GO; PEREIRA, AS; SUINAGA, FA; CARVALHO, ADF. 2014b. Rendimento de tubérculos de clones elite de batata. Horticultura Brasileira 32: 230-233.

SIMON, GA; PINTO, CABP; LAMBERT, ES; ANDREU, MA. 2009. Seleção de clones de batata resistentes à pinta preta e tolerantes ao calor. Ceres 56: 31-37.

SMITH, O. 1975. Potato chips. In: TALBURT, WF; SMITH, O. (eds). Potato processing. Westport: AVI, 3rd ed: 305-402. 